\title{
PREVIOUS CULTIVATION OF PALISADE GRASS AND SOIL CORRECTIVES: INFLUENCE ON GROWTH AND YIELD OF SOYBEAN CULTIVATED UNDER VARIOUS SOIL COMPACTION LEVELS
}

\author{
Cultivo prévio de braquiarão e corretivos de solo: influência sobre o \\ crescimento e produção da soja cultivada sob vários níveis de compactação do solo
}

\author{
Marcos André Silva Souza ${ }^{1}$, Douglas Ramos Guelfi Silva², Fabrício William Ávila ${ }^{3}$, \\ Valdemar Faquin², Geraldo César de Oliveira², Carla Elisa Alves Bastos ${ }^{2}$
}

\begin{abstract}
Soil compaction directly interferes on crop yield. The objectives of this work were to evaluate the effect of previous cultivation with palisade grass [Urochloa brizantha (C. Hochstetter ex A. Rich.) R. Webster cv. Marandu] and the use of soil correctives on the growth and yield of soybeans (Glycine max L.) cultivated under various soil compaction levels, in greenhouse conditions. The experiment was conducted in pots (columns) of $0.2 \mathrm{~m}$ diameter PVC tubes, composed of two rings: the lower ring, $0.4 \mathrm{~m}$ in height, received the soil (dystrophic Red Latosol, clayey texture) without corrective and a density of $1.0 \mathrm{Mg} \mathrm{m}^{-3}$; and the upper ring, $0,2 \mathrm{~m}$ in height, received the treatments of soil correctives and density. The experimental design was fully randomized in a 4 × 6 × 2 factorial outline, being four soil density levels $\left(1.0 ; 1.20 ; 1.40\right.$ and $1.60 \mathrm{Mg} \mathrm{m}^{-3}$ ), six soil correctives (without corrective, lime, calcium silicate, gypsum, lime + gypsum and calcium silicate + gypsum) and two cultivation systems of the soybean (with and without previous cultivation of palisade grass). Starting from $1.2 \mathrm{Mg} \mathrm{m}^{-3}$ of soil density the soybean growth and yield were decreased. The use of soil correctives and previous soil cultivation with palisade grass decreased the harmful effects of the soil compaction on the soybean growth and yield. For the treatments that received previous cultivation with palisade grass, the soybean growth and yield were higher with application of lime + gypsum and calcium silicate + gypsum.
\end{abstract}

Index terms: Urochloa brizantha, Glycine max, soil density, crop sequence.

\section{RESUMO}

A compactação do solo interfere diretamente sobre a produção das culturas. Neste trabalho, objetivou-se avaliar o efeito do cultivo prévio do braquiarão e o uso de corretivos do solo sobre o crescimento e produção da soja cultivada sob solo com vários níveis de compactação, em condições de casa de vegetação. O experimento foi conduzido em vasos (colunas) de tubos de PVC de $0,2 \mathrm{~m}$ de diâmetro, compostos por dois anéis: o anel inferior, de $0,4 \mathrm{~m}$ de altura, recebeu o solo (Latossolo Vermelho distrófico de textura argilosa) sem corretivo e densidade de $1,0 \mathrm{Mg} \mathrm{m}^{-3}$; e o anel superior, com $0,2 \mathrm{~m}$ de altura, recebeu os tratamentos de corretivos do solo (sem correção, calcário, silicato de cálcio, gesso, calcário + gesso e silicato de cálcio + gesso) e de compactação $(1,0 ; 1,20 ; 1,40$ e 1,60 $\mathrm{Mg} \mathrm{m}^{-3}$ de densidade) do solo. O delineamento experimental foi inteiramente casualizado em esquema fatorial 4 × 6 × 2 , sendo quatro densidades de solo, seis corretivos de solo e dois sistemas de cultivo da soja, com e sem cultivo prévio do braquiarão. A partir de 1,2 $\mathrm{Mg} \mathrm{m}^{-3}$ de densidade de solo, foi observada redução no crescimento e produção de grãos da soja. O uso de corretivos e o cultivo prévio do solo com braquiarão amenizam os efeitos deletérios da compactação do solo sobre o crescimento e produção da soja. Para os tratamentos que receberam cultivo prévio de braquiarão, a mistura de calcário + gesso e silicato de cálcio + gesso foram os corretivos que proporcionaram maior crescimento e produção da soja.

Termos para indexação: Urochloa brizantha, Glycine max, densidade do solo, sucessão de culturas.

(Received in june 5, 2011 and approved in september 9, 2011)

\section{INTRODUCTION}

The frequent use of machines and agricultural implements have been some of the main causes of soil compaction, interfering negatively on the yield and sustainability of agricultural systems. According to Stone e Silveira (2001) different cultivation systems present various behaviors as to the effect on the soil compaction.
The conventional cultivation system is noted for soil preparation with the use of the plow, harrow and subsoiler, directly influencing the soil structure (BILIBIO et al., 2010). On the other hand, conservation cropping systems have been highlighted recently, such as no-tillage and crop-livestock integration. The use of crop rotation and succession in those systems has been promoting lesser soil degradation by erosion, better use of the applied

\footnotetext{
${ }^{1}$ Universidade de Rio Verde, FES/URV - Fazenda Fontes do Saber - Rio Verde - GO - Brasil

${ }^{2}$ Universidade Federal de Lavras/UFLA - Departamento de Ciência do Solo - Lavras - MG - Brasil

3Universidade Federal de Lavras/UFLA-Departamento de Ciência do Solo-Cx.P. 3037-37200-000-Lavras - MG-Brasil - fabriciowilliamavila@yahoo.com.br
} 
inputs, higher nutrient cycling and soil structure recovery (GARCÍA-PRÉCHAC et al., 2004; MARCHÃO, 2007; BALBINOT JÚNIOR et al., 2008). Furthermore, the decomposition of plant residues originating from covering plants increases the moisture and nutrient concentration in the surface layer of the soil.

Among the various management systems of crop succession and rotation, the alternate cultivation of grasses and legumes has frequently been adopted. The grasses, besides supplying food for cattle, leave most of the soil covered, decompose slower and increase the soil aggregation through their fasciculate root system. The legumes fix atmospheric nitrogen, making available this nutrient for the subsequent crop (FONSECA et al., 2007).

Besides the cultivation system, the soil acidity is another property that should be corrected to mitigate the harmful effects of soil compaction on crop yield. According to Sousa and Lobato (2004), much Brazilian soil presents $\mathrm{pH}$ values in water less than 5.5, low calcium and magnesium levels and a high aluminum concentration. Therefore, the use of liming materials for soil acidity correction can promote beneficial alterations on the chemical and biological attributes of the soil, increasing crop yield and grain quality (PÁDUA et al., 2008; VEIGA et al., 2010). Oxides, hydroxides, silicates and carbonates are the most used soil liming materials in modern agriculture. Agricultural gypsum, although not a corrective of soil acidity, has been widely used to reduce aluminum toxicity in acid soils and to supply calcium and sulfur to the plants, thus increasing the root system growth in deep and consequently improving water and nutrient uptake (CAIRES et al., 2003).
The objectives of this work were to evaluate the effect of previous cultivation with palisade grass and the use of soil correctives on the growth and yield of soybean cultivated under various soil compaction levels, in greenhouse conditions.

\section{MATERIAL AND METHODS}

The experiment was conducted in a greenhouse at the Soil Science Department of the Federal University of Lavras (UFLA), Lavras-MG, using samples of the horizon B of a dystrophic Red Latosol of clayey texture, collected at the campus of the UFLA. Later, after sieving through 2 $\mathrm{mm}$ mesh sieve, soil subsamples were characterized chemically, physically and mineralogically according to Embrapa (1999) (Table 1).

The experiment was conducted in pots (columns) of 0,2 $\mathrm{m}$ diameter PVC tubes, composed by two rings to simulate a field condition: the lower ring, 0,4 $\mathrm{m}$ in height, received the soil without correction and a density of 1.0 $\mathrm{Mg} \mathrm{m}^{-3}$; and the upper ring, 0,2 $\mathrm{m}$ of height, received the treatments of soil correctives and density. The experimental design was completely random in a $4 \times 6 \times 2$ factorial outline, being four soil density levels $(1.0 ; 1.20$; 1.40 and $1.60 \mathrm{Mg} \mathrm{m}^{-3}$ ), six soil correctives (without corrective, lime, calcium silicate, gypsum, lime + gypsum and calcium silicate + gypsum) and two cultivation systems of the soybean (Glycine max L. cv. Conquista): with and without previous cultivation of the palisade grass [Urochloa brizantha (C. Hochstetter ex A. Rich.) R. Webster cv. Marandu].

The lime dose applied in the soil was estimated by the method of $\mathrm{Al}^{+3}$ neutralization and elevation of the $\mathrm{Ca}^{+2}$ and $\mathrm{Mg}^{+2}$ levels (ALVAREZ VENEGAS;

Table 1 -Chemical, physical and mineralogical attributes of the soil samples, prior to treatments.

\begin{tabular}{|c|c|c|c|c|c|c|c|c|c|c|c|c|c|}
\hline \multicolumn{14}{|c|}{ Chemical } \\
\hline $\mathrm{pH}_{\text {water }}$ & $\mathrm{P}_{(\text {Mehlich-1) }}$ & $\mathrm{K}$ & $\mathrm{S}$ & $\mathrm{Zn}$ & $\mathrm{Cu}$ & $\mathrm{Mn}$ & $\mathrm{Fe}$ & $\mathrm{Ca}$ & $\mathrm{Mg}$ & $\mathrm{Al}$ & $\mathrm{H}+\mathrm{Al}$ & $\mathrm{T} \quad \mathrm{m}$ & $\mathrm{OM}$ \\
\hline & -------------. & ---- & $(\mathrm{mg} \mathrm{d}$ & $m^{-3} o$ & ( soil) & ------ & -------- & -----. & $-(\mathrm{cn}$ & $l_{\mathrm{c}} \mathrm{dm}^{-}$ & of soil) & ---- -(\%)- & $\left(\mathrm{g} \mathrm{kg}^{-1}\right)$ \\
\hline 4.4 & 0.7 & 19.0 & 10.0 & 1.0 & 1.8 & 10.2 & 35.0 & 0.1 & 0.1 & 0.8 & 7.0 & $7.3 \quad 76$ & 0.3 \\
\hline \multicolumn{14}{|c|}{ Physical } \\
\hline \multicolumn{5}{|c|}{ Sand } & \multicolumn{5}{|c|}{ Silt } & \multicolumn{4}{|c|}{ Clay } \\
\hline \multicolumn{5}{|c|}{210} & \multicolumn{5}{|c|}{90} & \multicolumn{4}{|c|}{700} \\
\hline \multicolumn{14}{|c|}{ Mineralogical } \\
\hline \multicolumn{3}{|c|}{$\mathrm{SiO}_{2}$} & \multicolumn{3}{|c|}{$\mathrm{Al}_{2} \mathrm{O}_{3}$} & \multicolumn{3}{|c|}{$\mathrm{Fe}_{2} \mathrm{O}_{3}$} & \multicolumn{3}{|c|}{$\mathrm{TiO}_{2}$} & $\mathrm{Ki}$ & $\mathrm{Kr}$ \\
\hline \multicolumn{3}{|c|}{129.8} & \multicolumn{3}{|c|}{319.1} & \multicolumn{3}{|c|}{171.8} & \multicolumn{3}{|c|}{22.0} & 0.41 & 0.26 \\
\hline
\end{tabular}


RIBEIRO, 1999). In this work, the mixture of calcium carbonate $\left(\mathrm{CaCO}_{3}\right)$ and magnesium carbonate $\left(\mathrm{MgCO}_{3}\right)$, both p.a grades, was considered as lime. The dose of calcium silicate $\left(\mathrm{CaSiO}_{3}\right.$ of pa grade) applied in the soil was expressed in equivalent of calcium carbonate (ALVARDE; RODELLA, 1996), and the dose of gypsum $\left(\mathrm{CaSO}_{4} \cdot 2 \mathrm{H}_{2} \mathrm{O}\right.$ of pa grade) applied in the soil was estimated based on the soil texture (ALVAREZ VENEGAS et al., 1999).

In all of the treatments, macro and micronutrient fertilization was carried out in the soil of the upper ring using PA sources (MALAVOLTA, 1980), before the application of the soil compaction treatments. The treatments with lime, calcium silicate, lime + gypsum and calcium silicate + gypsum were mixed in the soil of the upper ring and incubated for 45 days (with moisture maintained around the field capacity) before the application of the soil compaction treatments; while the treatment with gypsum was applied on the surface of the pots after soil compaction and incubated for 30 days with moisture maintained around the field capacity. For the application of the soil compaction treatments, the soil moisture was corrected to $15 \%$, and the various compaction levels were obtained through a hydraulic press. During the soil compaction process, the PVC ring was placed inside another metallic ring ( $3 / 8$ "steel plate) of the same dimensions, to reinforce and avoid deformation or rupture of the PVC tube pot by the soil compression.

The previous cultivation with palisade grass was carried out with five plants per pot (PVC tube), which were submitted to three cuts at five centimeters from the soil surface, at intervals of 30 days. After the last cut, the palisade grass stayed for resprouting for 15 days before seeding the soybean, when desiccation with glyphosate was done at a dose of $4 \mathrm{~L} \mathrm{ha}^{-1}$. The dry mass of palisade grass produced was cut in pieces from 0,03 to $0,05 \mathrm{~m}$ and deposited on the surface of the pots at a dose of $22.16 \mathrm{~g} \mathrm{pot}^{-1}$, equivalent dose of $6.4 \mathrm{t} \mathrm{ha}^{-1}$, slightly below the dose used by Corrêa et al. (2004) of $8.0 \mathrm{t} \mathrm{ha}^{-1}$. Those pots were incubated for 60 days with moisture maintained around the field capacity, and they received a macro and micronutrient fertilization as basal dressing in the form of nutrient solution (using p.a. sources), with $50 \%$ of the dose recommended by Malavolta (1980), seeking to restore the nutrients extracted by palisade grass shoot.

Soon afterwards, the pots previously cultivated with palisade grass (cultivated system) as well as those that remained at rest (non-cultivated system), were sown with about 10 soybean seeds per pot, being thinned to three plants at 10 days after emergence (DAE). Daily irrigations were conducted with deionized water in order to maintain the soil moisture around the field capacity. Nitrogen and potassium fertilizations as top dressing were also done during the soybean growth period in both cultivation systems, according to Malavolta (1980).

At the flowering of the soybean, the leaf area was analyzed on a newly mature leaf (trifoliate leaf) of each plant of the pot using a CI-203 Laser Area Meter. At the end of the crop cycle, the shoot and grains of plants were harvested. Those were dried for 72 hours at $65-70^{\circ} \mathrm{C}$ in a forced draught oven, weighed (for obtaining the dry matter weight) and weighed, obtaining the shoot dry mass and the grain yield.

The data obtained was submitted to variance analysis using the SISVAR software (FERREIRA, 2003). The effect of the soil density on the variables was verified by polynomial regression analysis.

\section{RESULTS AND DISCUSSION}

In the treatment without previous cultivation of palisade grass and without supply of soil correctives, at all soil compaction levels, the plants presented typical symptoms of Mn toxicity and low growth soon after emergence, and they dried completely about 10 DAE (Figures 1a and 1b). However, when the palisade grass was cultivated previously, the soybean cultivated without supply of soil correctives completed their cycle (Figures 1c and 1d), but presented growth well below the plants under application of soil correctives. Those results show that the previous cultivation with palisade grass, under the conditions of this work, lessens the harmful effects of soil acidity on the growth and yield of soybean, but it does not substitute the application of soil correctives. Due to the low growth, the plants cultivated without application of soil correctives, with as well as without the previous cultivation of the palisade grass, were not measured.

The Figure 2, whose regression equations are presented in Table 2, shows that the previous cultivation with palisade grass, independent of the application of soil correctives, caused growth and yield values significantly higher than those of the treatments without previous cultivation of the palisade grass, and that effect increased with the increase of the soil density values. We also observed that the increase of the soil density caused a significant decrease in the soybean growth and yield, and that decrease was more drastic in the system without previous cultivation of the palisade grass. 
(a)

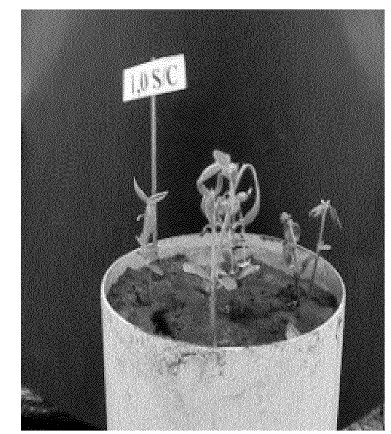

(b)

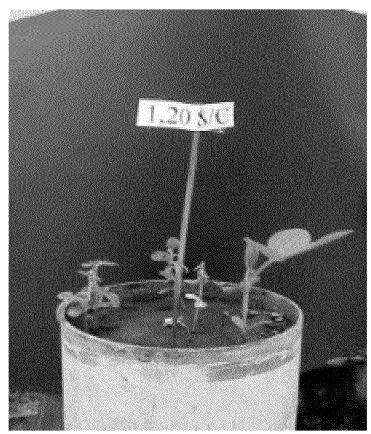

(c)

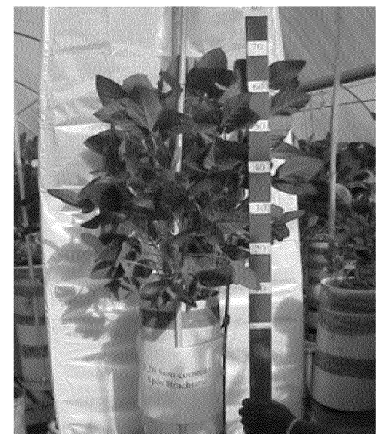

(d)

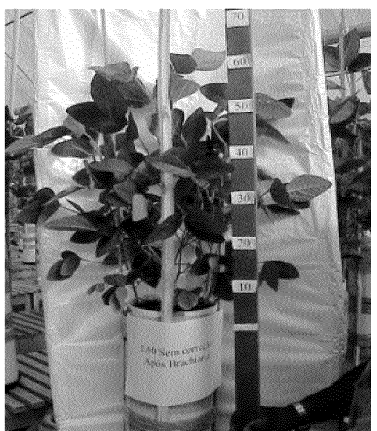

Figure 1-Details of the growth and visual aspect of the soybean at 10 DAE cultivated without supply of soil correctives and without previous cultivation of the palisade grass under soil densities of 1.0 (a) and 1.20 (b) $\mathrm{Mg} \mathrm{m}^{-3}$; and of the soybean at the onset of flowering cultivated without supply of soil correctives but with previous cultivation of the palisade grass under soil densities of 1.2 (c) and 1.6 (d) $\mathrm{Mg} \mathrm{m}^{-3}$.

(a)

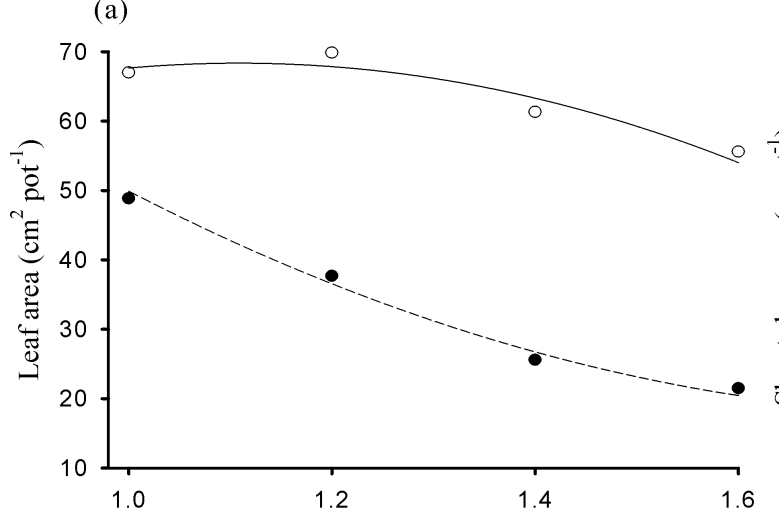

-With cultivation of palisade grass

(b)

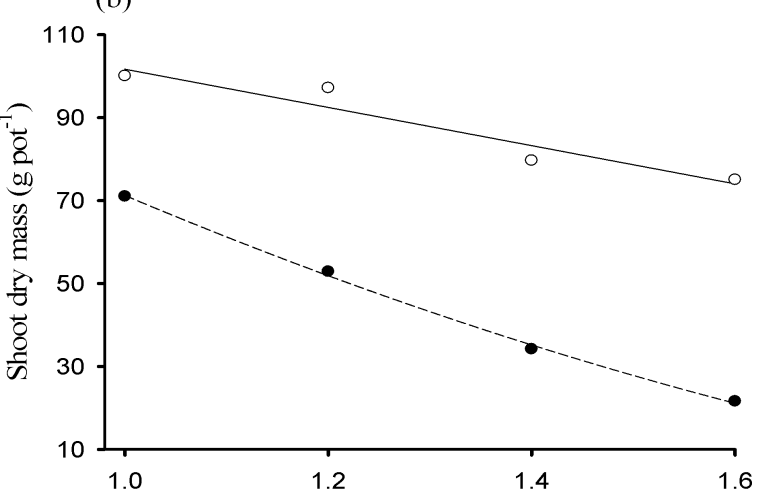

(c)

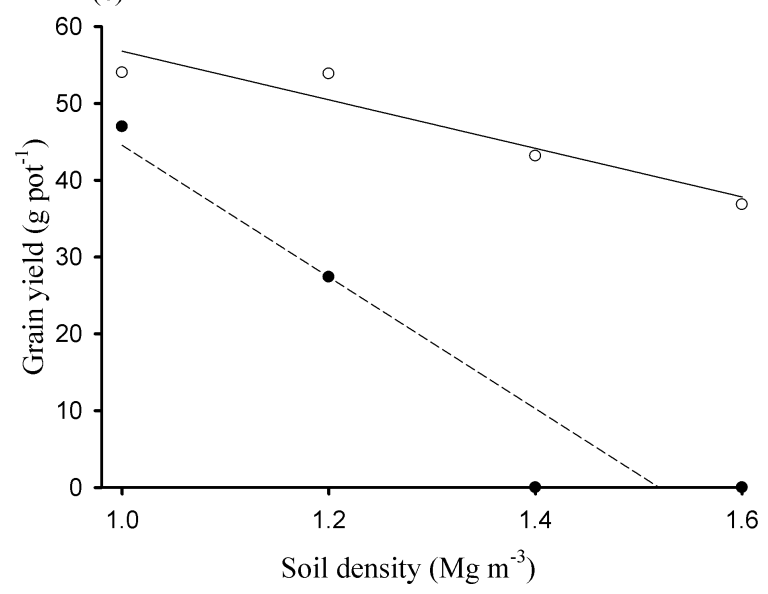

Figure 2 - Leaf area (a), shoot dry mass (b) and grain yield (c) of the soybean cultivated in pots with and without previous cultivation of the palisade grass, in function of the soil density. 
Table 2 - Regression equations for leaf area, shoot dry mass and grain yield of the soybean cultivated in pots with and without previous cultivation of the palisade grass, in function of the soil density.

\begin{tabular}{|c|c|}
\hline Cultivation systems & Regression equations \\
\hline \multirow{3}{*}{\multicolumn{2}{|c|}{$\begin{array}{ll} & \\
\text { Without cultivation of palisade grass } & \hat{y}=40.94 \mathrm{x}^{2}-155.89 \mathrm{x}+164.8 \mathrm{R}^{2}=0.96 * \\
\text { With cultivation of palisade grass } & \hat{\mathrm{y}}=-59.31 \mathrm{x}^{2}+131.48 \mathrm{x}-4.52 \mathrm{R}^{2}=0.93^{*}\end{array}$}} \\
\hline & \\
\hline & \\
\hline \multicolumn{2}{|c|}{ - } \\
\hline Without cultivation of palisade grass & $\hat{y}=33.06 x^{2}-169.48 x+207.65 \quad R^{2}=0.99 *$ \\
\hline With cultivation of palisade grass & $\hat{y}=-46.07 x+147.75 R^{2}=0.87 *$ \\
\hline \multicolumn{2}{|c|}{ 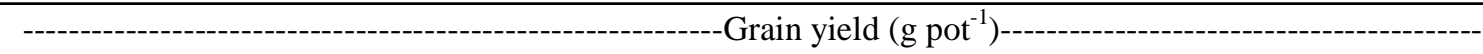 } \\
\hline Without cultivation of palisade grass & $\hat{y}=-85.69 x+130.22 R^{2}=0.90 *$ \\
\hline With cultivation of palisade grass & $\hat{y}=-31.61 x+88.40 \quad R^{2}=0.90 *$ \\
\hline
\end{tabular}

* Significant to $5 \%$ of probability.

The soil density of $1.6 \mathrm{Mg} \mathrm{m}^{-3}$ without previous cultivation of the palisade grass was highly limiting to the soybean growth and yield, promoting reductions of 59, 70 and $100 \%$ in the leaf area, shoot dry mass and grain yield values, respectively, when compared with the soil density of $1.0 \mathrm{Mg} \mathrm{m}^{-3}$. However, those limitations of the $1.6 \mathrm{Mg} \mathrm{m}^{-3}$ soil density were much lower when the soil was previously cultivated with palisade grass, in which reductions of 20, 23 and $33 \%$ were observed for the leaf area, shoot dry mass and grain yield values, respectively, in comparison with the soil density of $1.0 \mathrm{Mg} \mathrm{m}^{-3}$. Those results show that the previous cultivation with palisade grass lessened the harmful effects of the soil compaction on the growth and grain yield of soybean.

The root system of the palisade grass is able to cross the compressed soil layer and, after its decomposition, channel formation in the soil occurs, which increases aeration and permeability, reducing the soil compaction effects on the succession crop (MÜLLER et al., 2001; ABREU et al., 2004). According to Stone and Silveira (2001), crop rotation employing grasses and legumes can recover the physical structure of the soil and condition good root development of the succession crop, resulting in larger growth of its shoot.

The Figure 3, whose regression equations are presented in Table 3, shows the individual effect of the soil correctives on the growth variables and grain yield of the soybean, in function of the soil density for each cultivation system. As already noted, the treatments without soil corrective application (control) was not included in the evaluations due to the low growth of the plants (Figure 1).

It can be observed that, in general, in the system without previous cultivation of the palisade grass (Figures
$3 a, 3 c$ and $3 e$ ) there were small differences among the effects of the different soil correctives on the shoot dry mass and grain yield of the soybean grown in the lower soil density values. At the high soil density values, the grain yield (Figure 3e) was drastically reduced for all the applied soil correctives, and from soil density of $1.40 \mathrm{Mg}$ $\mathrm{m}^{-3}$, no grain yield was obtained. This result agrees with Beutler and Centurion (2004), who report a soil density of $1.37 \mathrm{Mg} \mathrm{m}^{-3}$ as restrictive to soybean yield.

However, in the system with previous cultivation of the palisade grass (Figures $3 \mathrm{~b}, 3 \mathrm{~d}$ and $3 \mathrm{f}$ ) a more pronounced effects of the soil correctives on the measured variables was observed, even at the highest soil density value $\left(1.60 \mathrm{Mg} \mathrm{m}^{-3}\right)$. With the previous cultivation of palisade grass, a lessening of the negative effects of the soil compaction through the reduction of the mechanical impedance of the compressed layer probably occurred, mainly at the highest densities (1.40 and $\left.1.60 \mathrm{Mg} \mathrm{m}^{-3}\right)$. Allied to that fact, alterations occurred by the effect of the organic matter, originating from the palisade grass root decomposition, allowed higher aeration and permeability as a consequence of the canaliculi left after root decomposition. These results agree with those found by Silva and Rosolem (2001) for the soybean.

Among the soil correctives, in both cultivation systems, the isolated application of the gypsum, in general, was the treatment that exhibited the lowest growth and grain yield values of the soybean. For the other soil correctives, there were no considerable differences among them, but the mixtures of lime + gypsum and silicate + gypsum, in general, exhibited the highest values for the growth variables and grain yield evaluated. 

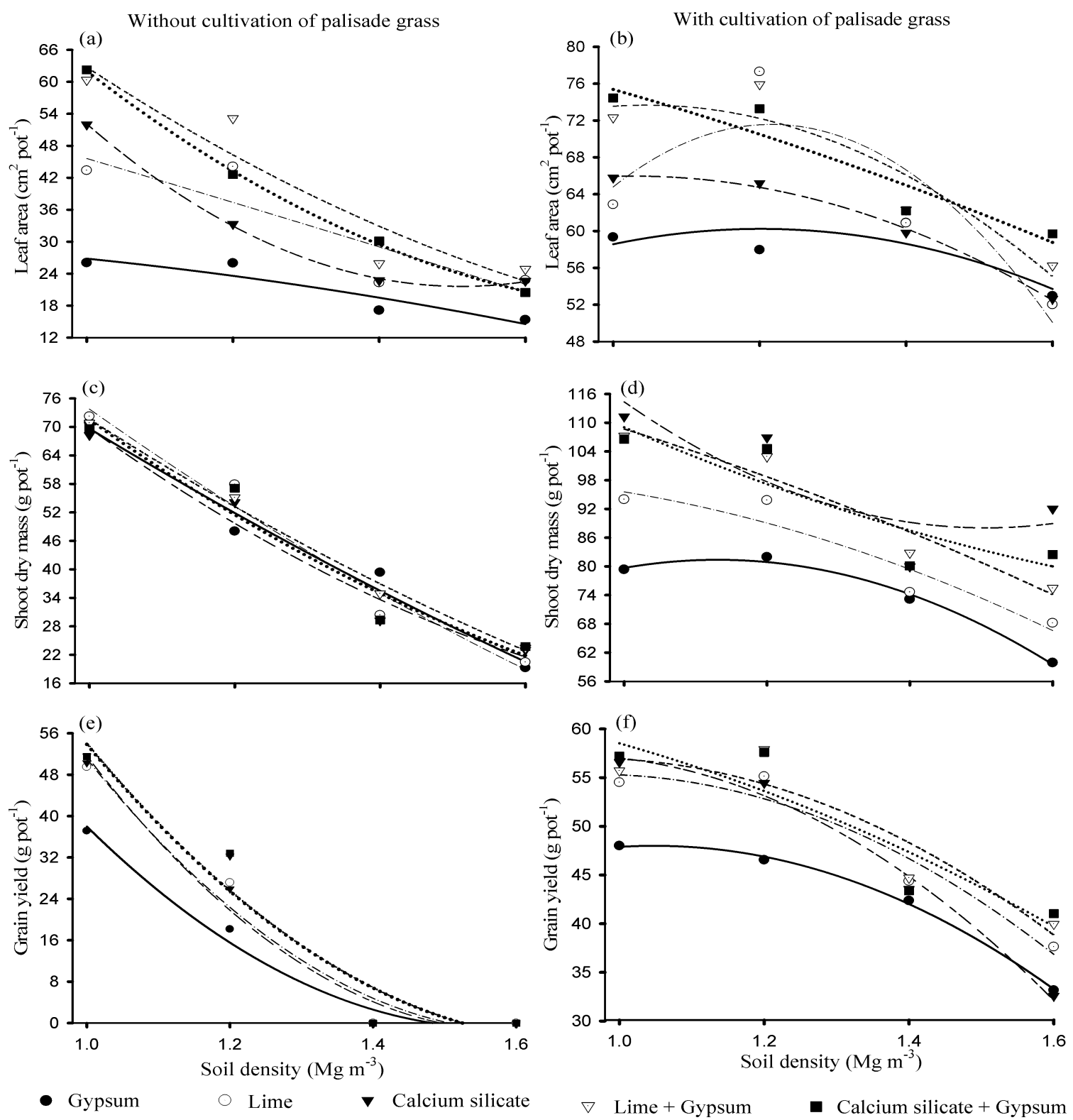

Figure 3 - Leaf area (a and b), shoot dry mass (c and d) and grain yield (e and f) of the soybean cultivated in pots with and without previous cultivation of the palisade grass, and under supply of different soil correctives, in function of the soil density.

The smallest effect of the gypsum, probably was the result of the high acidity of the soil under natural conditions (Table 1). The $\mathrm{Al}^{+3}$ and $\mathrm{Mn}^{+2}$ toxicity allied to low bases saturation are the factors that most limit agricultural yield in acid soils of the tropics (SOUZA; LOBATO, 2004). However, even with that limitation, the isolated application of gypsum allowed the soybean to reach the end of the cycle in both cultivation systems, which did not take place when soil correctives were not applied in the system without previous cultivation of palisade grass. Although the gypsum does not alter the soil $\mathrm{pH}$ values, the lessening of $\mathrm{Al}^{+3}$ toxicity and supply of $\mathrm{Ca}$ and $\mathrm{S}$ are the main benefits of the gypsum on growth of the crops under acid soil. 
The last three columns of table 3 show the estimated leaf area, shoot dry mass and grain yield values for the soil densities of 1.0 and $1.6 \mathrm{Mg} \mathrm{m}^{-3}$, and the reduction percentage of those variables among those soil density values. In general there was a drastic effect of the soil compaction on the values of the studied variables, that effect being lessened by the previous cultivation of palisade grass.

Table 3 - Regression equations for leaf area, shoot dry mass and grain yield of the soybean cultivated in pots with and without previous cultivation of the palisade grass, and under supply of different soil correctives, in function of the soil density. Also presented are the estimated values of leaf area, shoot dry mass and grain yield for the soil densities of 1.0 and $1.60 \mathrm{Mg} \mathrm{m}^{-3}$, and the reduction percentage of those values between the respective soil densities.

\begin{tabular}{|c|c|c|c|c|}
\hline \multirow[t]{2}{*}{ Cultivation systems } & \multirow[t]{2}{*}{ Regression equations } & \multicolumn{2}{|c|}{$\begin{array}{l}\text { Soil density } \\
\left(\mathrm{Mg} \mathrm{m}^{-3}\right)\end{array}$} & \multirow[t]{2}{*}{ Reduction $(\%)$} \\
\hline & & 1.00 & 1.60 & \\
\hline \multicolumn{5}{|c|}{ Without cultivation of palisade grass } \\
\hline Gypsum & $\hat{y}=-10.75 x^{2}+7.48 x+30.09 R^{2}=0.87 *$ & 26.8 & 14.5 & 45 \\
\hline Lime & $\hat{y}=-1.38 x^{2}-38.18 x+85.17 \quad R^{2}=0.77 *$ & 45.6 & 20.5 & 54 \\
\hline Calcium silicate & $\hat{y}=116.19 x^{2}-351.39 x+287.3 \quad R^{2}=0.99 *$ & 52.1 & 22.5 & 56 \\
\hline Lime + Gypsum & $\hat{y}=38.38 x^{2}-166.63 x+190.91 \quad R^{2}=0.89^{*}$ & 62.6 & 22.5 & 64 \\
\hline Calcium silicate + Gypsum & $\hat{y}=62.38 x^{2}-231.07 x+230.72 \quad R^{2}=0.99 *$ & 62.0 & 20.7 & 66 \\
\hline \multicolumn{5}{|c|}{ With cultivation of palisade grass } \\
\hline Gypsum & $\hat{y}=-41.06 x^{2}+98.67 x+0.96 \quad R^{2}=0.67 *$ & 58.5 & 53.7 & 8 \\
\hline Lime & $\hat{y}=-145.62 x^{2}+354.1 x-143.69 R^{2}=0.78^{*}$ & 64.7 & 50.0 & 22 \\
\hline Calcium silicate & $\hat{y}=-41.19 x^{2}+84.66 x+22.45 \quad R^{2}=0.99 *$ & 65.9 & 52.4 & 20 \\
\hline Lime + Gypsum & $\hat{y}=-60.5 x^{2}+126.37 x+7.68 R^{2}=0.87 *$ & 73.5 & 54.0 & 25 \\
\hline Calcium silicate + Gypsum & $\hat{y}=-8.38 x^{2}-5.90 x+89.65 \quad R^{2}=0.90 *$ & 75.3 & 58.0 & 22 \\
\hline \multicolumn{5}{|c|}{ Without cultivation of palisade grass } \\
\hline Gypsum & $\hat{y}=17.56 x^{2}-127.51 x+179.59 R^{2}=0.98^{*}$ & 69.6 & 20.5 & 70 \\
\hline Lime & $\hat{y}=27.38 x^{2}-162.59 x+208.98 \quad R^{2}=0.97 *$ & 73.7 & 18.9 & 74 \\
\hline Calcium silicate & $\hat{y}=49.75 x^{2}-209.65 x+229.63 R^{2}=0.95^{*}$ & 69.7 & 21.5 & 69 \\
\hline Lime + Gypsum & $\hat{y}=26.82 x^{2}-150.9 x+195.59 \quad R^{2}=0.99 *$ & 71.5 & 22.8 & 68 \\
\hline Calcium silicate + Gypsum & $\hat{y}=43.5 x^{2}-195.82 x+223.82 R^{2}=0.95^{*}$ & 71.5 & 21.0 & 69 \\
\hline \multicolumn{5}{|c|}{ With cultivation of palisade grass } \\
\hline Gypsum & $\hat{y}=-99.25 x^{2}+224.47 x-45.54 \quad R^{2}=0.99 *$ & 79.6 & 59.5 & 25 \\
\hline Lime & $\hat{y}=-39.19 x^{2}+53.61 x+81.13 \quad R^{2}=0.90 *$ & 95.5 & 95.5 & 36 \\
\hline Calcium silicate & $\hat{y}=102.81 x^{2}-309.66 x+321.2 R^{2}=0.69 *$ & 114.3 & 88.9 & 22 \\
\hline Lime + Gypsum & $\hat{y}=-19.12 x^{2}+7.97 x+135.74 \quad R^{2}=0.94 *$ & 108.6 & 73.7 & 32 \\
\hline Calcium silicate + Gypsum & $\hat{y}=27.31 x^{2}-119.42 x+201.15 \quad R^{2}=0.80 *$ & 109.0 & 79.9 & 26 \\
\hline \multicolumn{5}{|c|}{ Without cultivation of palisade grass } \\
\hline Gypsum & $\hat{y}=118.62 x^{2}-373.17 x+292.53 \quad R^{2}=0.98^{*}$ & 37.9 & 0.0 & 100 \\
\hline Lime & $\hat{y}=139.69 x^{2}-450.99 x+362.39 R^{2}=0.97 *$ & 51.0 & 0.0 & 100 \\
\hline Calcium silicate & $\hat{y}=152.31 x^{2}-484.37 x+334.43 R^{2}=0.98^{*}$ & 51.6 & 0.0 & 100 \\
\hline Lime + Gypsum & $\hat{y}=120.81 x^{2}-407.65 x+340.7 \quad R^{2}=0.95 *$ & 53.8 & 0.0 & 100 \\
\hline Calcium silicate + Gypsum & $\hat{y}=116.81 x^{2}-397.39 x+334.43 \quad R^{2}=0.94 *$ & 53.7 & 0.0 & 100 \\
\hline \multicolumn{5}{|c|}{ With cultivation of palisade grass } \\
\hline Gypsum & $\hat{y}=-48.38 x^{2}+101.42 x-5.17 \quad R^{2}=0.99 *$ & 47.8 & 33.2 & 30 \\
\hline Lime & $\hat{y}=-46.00 x^{2}+88.88 x+12.40 \quad R^{2}=0.94 *$ & 55.2 & 36.8 & 33 \\
\hline Calcium silicate & $\hat{y}=-55.25 x^{2}+102.2 x+10.05 \quad R^{2}=0.98 *$ & 57.4 & 32.5 & 43 \\
\hline Lime + Gypsum & $\hat{y}=-43.31 x^{2}+82.39 x+17.83 \quad R^{2}=0.87 *$ & 56.9 & 38.7 & 31 \\
\hline Calcium silicate + Gypsum & $\hat{y}=-17.13 x^{2}+13.18 x+62.48 R^{2}=0.85^{*}$ & 58.5 & 39.7 & 32 \\
\hline
\end{tabular}

Ciênc. agrotec., Lavras, v. 35, n. 6, p. 1132-1140, nov./dez., 2011 
Comparing the soil correctives at the densities of 1.0 and $1.6 \mathrm{Mg} \mathrm{m}^{-3}$ (Table 3), for all the variables, it was observed that the smallest effect of the gypsum in relation to the other correction treatments was quite evident at the density 1.0. However, for density $1.6 \mathrm{Mg} \mathrm{m}^{-3}$, the effects of the soil correctives were close, except the shoot dry mass and grain yield in the system with previous cultivation of palisade grass, where the treatment with only gypsum promoted lower values than the other liming materials. That observation demonstrates that with the increase of the soil compaction and, consequently, increased resistance to root penetration, in general there is lower shoot growth and grain yield by the decrease of soil aeration and permeability, also reducing the beneficial effects of soil correctives.

\section{CONCLUSIONS}

Soil density values starting from $1.2 \mathrm{Mg} \mathrm{m}^{-3}$, in the pots with as well as without previous cultivation of palisade grass, reduce the growth and grain yield of the soybean.

The previous cultivation with palisade grass and the use of soil correctives lessens the soil compaction effects on the growth and grain yield of the soybean, even at highly limiting soil density values, such as $1.6 \mathrm{Mg} \mathrm{m}^{-3}$.

Differentiated effects of the different soil correctives on the growth and grain yield of the soybean are more evident with the previous cultivation of palisade grass, and the best results being obtained with the application of the calcium silicate + gypsum or lime + gypsum mixtures.

The calcium silicate, when applied alone, had an effect similar to that of the lime on the growth and grain yield of the soybean.

\section{ACKNOWLEDGEMENTS}

The authors wish to thank the FAPEMIG for financial support, as well as $\mathrm{CNPq}$ for the award of a Postgraduate Fellowship.

\section{REFERENCES}

ABREU, S.L.; REICHERT, J.M.; REINERT, D.J.

Escarificação mecânica e biológica para a redução da compactação em Argissolo franco-arenoso sob plantio direto. Revista Brasileira de Ciência do Solo, Viçosa, v.28, n.3, p.519-531, 2004.

ALCARDE, J.A.; RODELLA, A.A. O equivalente em carbonato de cálcio dos corretivos da acidez dos solos. Scientia Agricola, Piracicaba, v.53, n.2/3, p.6-12, maio/ dez. 1996.
ALVAREZ VENEGAS, V.H.; RIBEIRO, A.C. Calagem. In: RIBEIRO, A.C.; GUIMARÃES, P.T.G; ALVAREZ VENEGAS, V.H. (Ed.). Recomendações para uso de corretivos e fertilizantes em Minas Gerais: $5^{\mathrm{a}}$ aproximação. Viçosa: UFV, 1999. p.43-60.

ALVAREZ VENEGAS, V.H. et al. Uso de Gesso Agrícola. In: RIBEIRO, A.C.; GUIMARÃES, P.T.G.; ALVAREZ VENEGAS, V.H. (Ed.). Recomendações para uso de corretivos e fertilizantes em Minas Gerais: $5^{\mathrm{a}}$ aproximação. Viçosa: UFV, 1999. p.67-78.

BALBINOT JÚNIOR, A.A. et al. Formas de uso do solo no inverno e sua relação com a infestação de plantas daninhas em milho (Zea mays) cultivado em sucessão. Planta Daninha, Viçosa, v.26, n.3, p.569-576, 2008.

BEUTLER, A.N.; CENTURION, J.F. Soil compaction and fertilization in soybean productivity. Scientia Agricola, Piracicaba, v.61, n.6, p.626-631, Nov./Dec. 2004.

BILIBIO, W.D.; CORRÊA, G.F; BORGES, E.N. Atributos físicos e químicos de um latossolo, sob diferentes sistemas de cultivo. Ciência e Agrotecnologia, Lavras, v.34, n4, p.817-822, jul./ago. 2010.

CAIRES, E.F. et al. Alterações químicas do solo e resposta da soja ao calcário e gesso aplicados na implantação do sistema plantio direto. Revista Brasileira de Ciência do Solo, Viçosa, v.27, n.2, p.275-286, mar./abr. 2003.

CORRÊA, J.C.; MAUAD, M.; ROSOLEM, C.A. Fósforo no solo e desenvolvimento de soja influenciados pela adubação fosfatada e cobertura vegetal. Pesquisa Agropecuária Brasileira, Brasília, v.39, n.12, p.12311237, dez. 2004.

EMBRAPA. Empresa Brasileira de Pesquisa Agropecuária. Manual de análises químicas de solos, plantase fertilizantes. Brasília, DF: Embrapa Solos/Embrapa Informática Agropecuária/Embrapa Comunicação para Transferência de Tecnologia, 1999. 370p.

\section{FERREIRA, D.F. SISVAR versão 4.2. Lavras: DEX/ UFLA, 2003.}

FONSECA, G.C. et al. Atributos fisicos, químicos e biológicos de latossolo vermelho distrófico de cerrado sob duas rotações de cultura. Pesquisa Agropecuária Tropical, Goiânia, v.37, n.1, p.22-30, mar. 2007. 
GARCÍA-PRÉCHAC, F. et al. Integrating no-till into crop-pasture rotations in Uruguay. Soil and Tillage Research, Amsterdam, v.77, n.1, p.1-13, May 2004.

MALAVOLTA, E. Elemento de nutrição de plantas. Piracicaba: Agronômica Ceres, 1980. 251 p.

MARCHÃO, R.L. et al. Qualidade física de um Latossolo Vermelho sob sistemas de integração lavoura-pecuária no Cerrado. Pesquisa Agropecuária Brasileira, Brasília, v.42, n.6, p.873-882, jun. 2007.

MÜLLER, M.M.L.; CECCON, G.; ROSOLEM, C.A. Influência da compactação do solo em subsuperfície sobre o crescimento aéreo e radicular de plantas de adubação verde de inverno. Revista Brasileira de Ciência do Solo, Viçosa, v.25, n.3, p.531-538, jul./set. 2001.

PÁDUA, T.R.P.; SILVA, C.A.; DIAS, B.O. Nutrição e crescimento do algodoeiro em latossolo sob diferentes coberturas vegetais e manejo de calagem. Ciência e
Agrotecnologia, Lavras, v.32, n5, p.1481-1490, set./out. 2008.

SILVA, R.H.; ROSOLEM, C.A. Influência da cultura anterior e da compactação do solo na absorção de macronutrientes em soja. Pesquisa Agropecuária Brasileira, Brasília, v.36, n.10, p.1269-1275, out. 2001.

SOUZA, D.M.G.; LOBATO, E. Cerrado: correção do solo e adubação. 2.ed. Brasília, Embrapa Informação Tecnológica, 2004. 416p.

STONE, L.F.; SILVEIRA, P.M. Efeitos do sistema de preparo e da rotação de culturas na porosidade e densidade do solo. Revista Brasileira de Ciência do Solo, Viçosa, v.25, n.2, p.395-401, 2001.

VEIGA, A.D. et al. Influência do potássio e da calagem na composição química, qualidade fisiológica e na atividade enzimática de sementes de soja. Ciência e Agrotecnologia, Lavras, v.34, n4, p.953-960, jul./ago. 2010. 